\title{
ЖИЗНЬ И НАУЧНАЯ ДЕЯТЕЛЬНОСТЬ А.Х. МАРГУЛАНА. ОБРАЗ УЧЕНОГО И ЧЕЛОВЕКА
}

\author{
(C) 2018 г. Д.А. Маргулан
}

\begin{abstract}
Алькей Хаканович Маргулан - феноменальное явление в истории отечественной науки, основоположник археологии и этнографии в Казахстане. А.Х. Маргулан был первопроходцем в исследовании духовных святынь своего народа, первооткрывателем веками скрытых тайн истории народа. Проехав десятки тысяч километров по Казахстану от его западных границ через весь Центральный Казахстан до северо-восточных и восточных пределов нашей родины, он открыл и описал памятники материальной культуры с эпохи бронзы и ранних кочевников до позднего средневековья, изучал обычаи и традиции казахов, эпические сказания, легенды и предания, места обитания протоказахских племен.
\end{abstract}

Ключевые слова: археология, А.Х. Маргулан, история науки, первооткрыватель, археолог, этнограф, фольклорист

Алькей Хаканович Маргулан родился 11 мая 1904 года в Акпетинской волости* [*ныне Баянаульский p-н Павлодарской обл. - прим. авт.]. Отец будущего ученого Хакан - прямой потомок знаменитого Олжабайбатыра, объединившегося совместно c Богенбай-батыром, Наурызбайбатыром, Кабанбай-батыром под знаменем Абылай-хана, отстоявших независимость родины в войне с джунгарами. Олжабай-батыр был ближайшим сподвижником Абылай-хана; его знаменосцем. Подвиги Олжабая воспевал Бухар-жырау, его воины слушали наставления Каздауысты Казыбека. Известно, что в 1772 г. Олжабай-батыр и Едиге-бий пишут письмо русской императрице Екатерине II с требованием вернуть северные казахские земли, Кулундинскую степь.
Зимовкой Олжабая были красивейшие окрестности озера Жасыбай, ныне это перевал Дулата, названный в честь сына Олжабая, бывшего в свое время управителем Айдабулской волости. Летом племя МалгозыАйдабол откочевывало на берег p. Шидерты. Отец Алькея Хакан и мама Нурила знали много народных сказок и легенд, дома звучали народные песни; стихи и песни Абая. Потомок Олжабая Алькей научился читать и писать в 5 лет, с юных лет знал наизусть эпосы «Кобланды», «Алпамыс», «Кер-оглы», «Козы-Корпеш и Баян-Сулу». В доме Хакана бывали Машхур-Жусуп Копеев, Жаяу Муса, Имантай Сатпаев и другие известные в степи люди.

Начальное образование Алькей получил в аульной школе. С 1915 г. он учился в трехклассной русской шко- 
ле в Баянауле; в 15 лет едет учиться в гимназию в Екатеринбург, но учеба оборвалась из-за гражданской войны. В 1919 г. Алькей Хаканович поступает на учительские курсы в г. Павлодаpe, живет в доме знаменитой певицы Майры, где впитывает напевы степи, кюи Таттимбета. После окончания курсов в 1920 г. возвращается в родной аул и работает учителем в Далбинской школе. В 1921 г. поступает в Семипалатинский педагогический техникум, директором которого был выдающийся казахский просветитель Абикей Зеинович Сатпаев. В 1939 г. Алькей Хаканович женится на дочери А.3. Сатпаева Раушан Абикеевне.

В годы учебы в Семипалатинске Алькей Хаканович сотрудничает в редакциях журнала «Тан» и газеты «Қазақ тілі». Здесь он знакомится с Мухтаром Омархановичем Ауэзовым, дружба с которым связывает его на долгие годы. Духовное наследие великого Абая становится в этот период темой исследований А.Х. Маргулана. Вместе с М.О. Ауэзовым они едут на родину Абая, в горы Чингизтау (Шыңғыстау), знакомятся с сыном Абая Турагулом и внуком Джабраилом, великолепно исполнявшим песни Абая. В эти же годы Алькей Хаканович знакомится с Магжаном Жумабаевым, крупнейшим казахским поэтом, их связывает сердечная дружба.

По совету М.О. Ауэзова в 1925 г. Алькей Хаканович едет в г. Ленинград, где поступает на литературный факультет Восточного института, одновременно посещает лекции в Ленинградском университете и Институте истории искусств. А.Х. Маргулан писал: «В этих вузах мне посчастливилось слушать лекции самых выдающихся ученых нашей страны: академика В.В. Бартольда по истории и археологии Средней Азии, академика С.Ф. Ольденбурга по индийскому фольклору и искусству, академика И.Ю. Крачковского - по арабской филологии, Е.Э. Бертельса - по персидской поэзии; С.Е. Малова - по древнетюркским языкам, А.Н. Самойловича - по литературе народов Средней Азии, академиков Н.Я. Марра, И.И. Мещанинова, Л.В. Щербы по языкознанию, выдающихся востоковедов В.В. Струве, Б.Я. Владимирцова, Б.М. Эйхенбаума, С.И. Руденко; А.Ю. Якубовского, известного географа Г.Е. Грум-Гржимайло. Благодаря усилиям этих корифеев мы, студенты, уже на 2 курсе чувствовали себя учеными»* [*из записей, сохранившихся в семейном архиве прим. авт.]. Ему особенно были близки работы крупнейшего тюрколога Е.Э. Бертельса, арабоведа, знатока и переводчика Корана И.Ю. Крачковского, эпосоведа В.М. Жирмунского, академиков К. Розанова, Е.В. Тарле.

Успешно осваивая основы наук, А.Х. Маргулан изучает первоисточники в богатейших архивах Ленинграда; увлекается сбором литературных и архивных материалов по истории и культуре казахского народа. В эти годы он занимается и литературной деятельностью. В его переводе казахский читатель впервые знакомится с произведениями выдающихся русских и зарубежных писателей.

В Ленинграде Алькей Хаканович знакомится с А. Затаевичем, приезжает вместе с ним на каникулы в родные края, где знаменитому музыковеду удалось записать много казахских народных песен.

В 1926-1927 гг. будущий ученый принимает участие в Казахстанской и Алтайской экспедициях Особого комитета по исследованию со- 
юзных и автономных республик АН СССР под руководством академика А.Е. Ферсмана и профессора С.И. Руденко. Знание А.Х. Маргуланом быта и обычаев, нравов и культуры казахского народа оказало большую практическую помощь в работе антропологического отряда экспедиции. Результатом участия Алькея Хакановича в работе экспедиции явилась публикация им первых научных работ о племенах найман и адай.

В 1929 г. Алькей Хаканович заканчивает учебу в Восточном Институте, успешно защитив дипломную работу о творчестве Абая, затем он работает в Комитете нового алфавита при Наркомпросе КазССР.

В 1931 г. А.Х. Маргулан поступает в аспирантуру Государственной академии истории материальной культуры (ГАИМК) в г. Ленинграде. Здесь он вплотную занимается изучением восточных источников под руководством академика С.Ф. Ольденбурга и члена-корреспондента АН СССР А.Ю. Якубовского, специализируется по археологии и искусству Восточного Туркестана, принимает участие в ряде археологических экспедиций, возглавляемых известными археологами С.И. Руденко, М.П. Грязновым, А.А. Миллером, Н.И. Репниковым, пишет статьи о наследии МашхурЖусупа Копеева, истории декабристов в Казахстане, казахской культуре и Алишере Навои; начинает изучать творчество Ч.Ч. Валиханова. В те же годы в ГАИМК учились А.П. Окладников, А.Н. Бернштам, С.П. Толстов, К.В. Сальников, И.И. Смирнов - будущий цвет советской науки.

Для кандидатской диссертации А.Х. Маргулан выбрал сложную, малоизученную и в наше время представляющую огромный научный интерес проблему «Историческое зна- чение ярлыков и пайдзе». По сути это была одна из первых попыток исследования письменных памятников кыпчакской этнокультурной общности. Справедливо считая кыпчакскую проблему ключевой в этногенезе казахского народа, Алькей Хаканович на протяжении всей жизни не упускал ее из поля зрения. Как известно, она тесно переплетена не только с этнической историей казахов, но и с историей тюркоязычных народов Средней Азии и Юго-Восточной Европы, поэтому исследования А.Х. Маргулана и ряда его учеников о кыпчаках проливают свет на историю многих народов Евразии. В 1943 г. им успешно защищена кандидатская диссертация. Высокую оценку работе дал известный востоковед Н.В. Кюнер.

С 1936 по 1938 гг. А.Х. Маргулан является стажером, а затем и научным сотрудником Института истории материальной культуры АН СССР. Однако начинаются годы сталинских репрессий. Увлеченность молодого ученого проблемами национальной культуры не остается незамеченной, за этим следуют арест, изоляция в каземате Петропавловской крепости. Чудом уцелев, А.X. Маргулан в дальнейшем неизменно находился под наблюдением органов, постоянно подвергался критике со стороны своих коллег. Так, партийный историк Б. Степанов в журнале «Большевик Казахстана» писал: «Доктор филологических наук Маргулан в своей книге “Эдыге в истории и преданиях” (1944 год) наделяет Эдыге - этого злейшего врага русского народа всеми лучшими чертами казахского народа, называет его истинным представителем народа» [Степанов, 1947, c. 41]. И далее Б. Степанов продолжает: «В книге А. Маргулана "О характере и исторической обусловлен- 
ности казахского эпоса", в которой обощен большой труд, автор не дал партийного освещения тех задач, какие должны были быть решены в этой книге. <.. > Извечная борьба за независимость, положенная в основу периодизации истории казахского эпоca, развитие производства, классовая борьба, чаяния и ожидания народных масс в борьбе против эксплуататоров - все это остается в тени» [Степанов, 1947, с. 42]. Подобные многочисленные пасквили и доносы послужили причиной того, что А.Х. Маргулан целиком погрузился в археологические изыскания. Но и здесь возможность спокойно работать была иллюзией, о чем свидетельствует тот факт, что в волну репрессий 1950-х гг. А.Х. Маргулан на несколько лет становится безработным.

В конце 1938 г. решением президиума АН СССР А.Х. Маргулан был направлен в Казахский филиал АН CCCP. C тех пор он непрерывно работал в системе КазФАН СССР, позднее преобразованном в Академию наук Казахской ССР. В 1941-1946 гг. он заведует сектором истории, с 1946 по 1951 г. - сектором археологии и отделом палеолита, с 1958 по 1976 гг. - отделом этнографии Института истории, археологии и этнографии им. Ч.Ч. Валиханова АН КазССР. С 1976 г. до конца жизни был старшим научным сотрудником отдела этнографии. Основательное образование в сочетании с пытливостью ума и исключительным трудолюбием обеспечило ему право первооткрывателя во многих областях казахстанской науки: археологии, истории племен региона, истории культуры и искусства, этнографии и филологии казахского народа.

С начала 1940-х гг. А.Х. Маргулан наряду с изучением письмен- ных памятников и исследованием духовной культуры и фольклора казахов одним из первых начинает заниматься поиском археологических памятников материальной культуры древних насельников Казахстана. По его инициативе был организован ряд археологических и этнографических экспедиций в самые глубинные районы казахских степей.

А.Х. Маргулан прошел маршрутами караванных путей и кочевок казахов тысячи и тысячи километров, отыскал десятки археологических памятников, всесторонне их исследовал и систематически описал. Он доказал, что Казахстан не был, как полагали до него многие исследователи, безжизненной пустыней, которую изредка пересекали кочевые пути номадов. Именно А.Х. Маргуланом были обнаружены и основательно изучены следы древней городской культуры Южного Казахстана в бассейнах рек Сырдарья, Талас и Шу. Он произвел предварительные археологические раскопки на Отраре, Таразе, Сайраме. Сыгнаке, Сарайшыке. Одновременно собирал казахские предания, легенды, эпические сказания. Результатом этих исследований стала изданная в 1950 г. монография «Из истории городов и строительного искусства древнего Казахстана», в которой впервые были описаны крупнейшие центры городской цивилизации, дан их глубокий, научно обоснованный анализ.

А.Х. Маргулан впервые поставил вопрос о наличии и взаимодействии в Казахстане различных типов хозяйственно-культурной деятельности, показал необходимость их всестороннего изучения, поскольку в то время преобладало мнение о том, что в археологическом отношении регион не представляет для науки 
Маргулан Д.А. Жизнь и научная деятельность А.Х. Маргулана....

интереса. Результатом его исследований в области истории культуры казахского народа явилась защита в 1945 г. докторской диссертации на тему «Эпические сказания казахского народа», в которой вопросы эпического жанра получили глубокое и всестороннее исследование. Высокую оценку работе дали академики В.А. Гордлевский и И.И. Мещанинов, члены-корреспонденты АН СССР В.М. Жирмунский и С.Е. Малов. В 1946 г. Казахский филиал АН СССР преобразуется в Академию наук Казахской ССР, а А.Х. Маргулан; как видный ученый республики, избирается ее членом-корреспондентом; в 1958 г. - действительным членом. В 1960 г. ему было присвоено звание профессора.

В послевоенное время по совету академика К.И. Сатпаева А.Х. Маргулан избирает объектом своих исследований Центральный Казахстан. Многолетние исследования позволили ученому открыть в регионе крупнейший очаг цивилизации эпохи бронзы и самобытную бегазыдандыбаевскую культуру. В течение трех десятилетий под руководством А.Х. Маргулана велись археологические изыскания памятников эпохи бронзы и ранних кочевников. Эти исследования способствовали пересмотру ряда теорий об основных этапах генезиса номадизма, процесса эволюции хозяйства и культуры древнейших насельников региона, роли этнокультурных связей. В наше время, благодаря этим исследованиям, стало общепризнанным положение о том, что генетическим дериватом андроновской этнокультурной общности явилась сакская культурная общность, в пределах которой эволюционировало скотоводческое хозяйство древних насельников, а ключевым связующим звеном между ними явилась бегазы-дандыбаевская культура [Маргулан, 2008б].

Об этой самобытной культуре, сконцентрировавшей лучшие творения древних жителей Сарыарки, свидетельствуют грандиозные мавзолеи, поселения древних рудокопов и металлургов, сохранившиеся до наших дней остатки металлургического производства. На основе огромного фактического материала ученый приходит к выводу, что горное дело и металлургия наряду со скотоводством и земледелием были древнейшими видами хозяйственной деятельности протоказахских племен. Об этом свидетельствуют многочисленные горные выработки и металлургические центры, появившиеся в древние времена и разбросанные по всей степи, как результат деятельности древних рудокопов и металлургов. Во многих древних рудниках Центрального Казахстана были обнаружены шахты, штольни, штреки, квершлаги. Для осуществления промывки и мокрой флотации руды существовали водосборные ямы, обнаружено большое число плавильных печей. На основании обнаруженных фактов ученый приходит к сенсационному выводу, что казахские степи благодаря богатейшим недрам были родиной металлической культуры, т.е. наши далекие пращуры принимали активное участие в становлении цивилизации на земле. Этот вывод ученого подтверждается открытыми в последнее время в разных странах архивными материалами. Горнорудный промысел и металлургия в древние времена достигли крупномасштабных форм производства, добыча руды в наиболее крупных разработках достигала сотен тысяч тонн, т.е. была значительной даже по современным мас- 
штабам. В результате крупных объемов выплавленной меди в те далекие времена появилась меновая стоимость и экспорт меди. О масштабах этой формы деятельности говорит факт экспорта меди по караванным путям в древний Рим, Китай и другие страны [Маргулан, 2008а].

А.Х. Маргулан всегда был многопланов в своих научных изысканиях, параллельно разрабатывал сразу несколько проблем, каждой из которых хватило бы для многолетнего изучения не одному десятку ученых. Со студенческих лет работая в архивах Ленинграда, Москвы, Омска и других городов, он по крупицам собирал материалы о выдающемся казахском ученом Ч.Ч. Валиханове, всесторонне исследовал его научные труды. Результатом неустанной работы в этом направлении стало издание избранных трудов Ч.Ч. Валиханова в 1958 г. В 1957-1967 гг. А.Х. Маргулан возглавил академическое издание собрания сочинений Ч.Ч. Валиханова в пяти томах. Этот огромный труд требовал от ученого колоссального напряжения и скрупулезного труда. А.Х. Маргуланом и его сотрудниками были выявлены десятки новых, прежде неопубликованных работ, рукописей, писем, записок. Необходимо было изучить наследие русских путешественников и ученых, современников Ч.Ч. Валиханова. Была проделана огромная работа по исследованию всего рукописного наследия Ч.Ч. Валиханова, составлению комментариев, объяснению различных сюжетов, уточнению достоверности сообщений и т.д. Результатом источниковедческой работы явилось пятитомное собрание сочинений великого казахского ученого, вышедшее в 1961-1972 гг. Вступительная статья А.Х. Маргулана о жизни и деятель- ности Ч.Ч. Валиханова определила целое научное направление - чокановедение [Маргулан, 1961]. К 150летнему юбилею со дня рождения ученого было подготовлено и выпущено под руководством А.Х. Маргулана второе издание. Алькей Хаканович планировал выпуск этого издания в шести томах, но осуществить этот замысел ему не удалось. Список источников для шестого тома сочинений Ч. Валиханова хранится в архиве ученого.

Прослеживается некоторое сходство подходов к проблемам истории у этих двух выдающихся казахских ученых. И тот и другой получили прекрасное европейское образование, для обоих характерно глубокое постижение русской культуры и масштабный подход к проблемам истории, а также других гуманитарных наук. Своему любимцу Алькей Хаканович посвятил две монографии. «Чокан и “Манас"» вышла в 1971 г. [Маргулан, 1971]. В этой работе А.Х. Маргулан на основе сравнительного исследования различных вариантов эпоса «Манас» дает блестящий его анализ, а также показывает конкретный вклад Ч.Ч. Валиханова в его изучение.

Особое место в творчестве А.Х. Маргулана занимает архитектура Казахстана. Для монографии «Архитектура Казахстана» ученый собирал материалы на протяжении нескольких десятилетий. Она посвящена истории и эволюции строительного дела и архитектуры на земле казахов, начиная с эпохи бронзы до позднего средневековья. Монография, состоящая из четырех частей: «Древняя архитектура Казахстана», «Доисламская архитектура», «Архитектура средневекового Казахстана», «Архитектура позднего средневеко- 
вья», оснащена огромным количеством комментариев и рисунков. Эта работа дает представление о совершенном чувстве композиции и гармонии, присущем нашим предкам [Маргулан, 2008в].

С точки зрения этнографии история материальной культуры кочевников и их преемников казахов представлена в фундаментальном труде «Казахское народное прикладное искусство», в котором системно представлены предметы быта казахов, одежда, жилище, предметы ювелирного искусства, их происхождение и эволюция. По существу это энциклопедия казахского прикладного искусства, оснащенная уникальным по полноте и сводным по характеру собранием шедевров народного художественного творчества [Маргулан, 2008г]. Этот фундаментальный труд в трех томах вышел уже после смерти ученого.

Важно остановиться еще на одной работе ученого «Древние казахские племена, история их объединений и образование Казахского ханства», где А.Х. Маргулан пишет о том, что на протяжении всего исторического времени существовала тенденция к сближению древних протоказахских племен, к образованию единого этноса. В раннее средневековье в истории казахов появляется объединение «Ушжуз,, в домонгольское время в результате усиления тенденции сближения племен появляется союз племен «алаш». Важнейшим этапом в процессе консолидации протоказахских племен было образование Казахского ханства. В работе А.Х. Маргулана «Древние казахские племена, история их объединений и образование Казахского ханства» - первого государства в истории казахов описан памятник, имеющий для казахов огромное историческое значение. Как пишет ученый, во времена образования Казахского ханства в 1467 г. на берегу р. Сарысу в Центральном Казахстане состоялся синклит, в котором приняли участие вожди крупных племен трех жузов, и на скале Тамгалы-тас была высечена надпись на кипчакском языке об объединении племен в единый казахский народ. Это место официального провозглашения казахского народа. В народе его называют «қазақтың ұран шақырып, қазақ біріккен жері» [Mapгулан, 2008д].

О своеобразии, глубине и насыщенности духовного мира наших предков свидетельствуют работы, посвященные легендам и эпическим сказаниям разных племен, истории письменности нашего народа. Поражает, с какой любовью и восхищением, как поэтически возвышенно писал он о культуре каждого из племен, образовавших казахский этнос. Сквозь время - это урок и упрек трайбалистам нашего времени.

Возглавляя в течение многих лет Центрально-Казахстанскую археологическую экспедицию и отдел этнографии, А.Х. Маргулан способствовал развитию археологии и этнографии в Казахстане. Им подготовлено не одно поколение казахстанских ученых, этнографов, археологов, историков. Среди его учеников - видные археологи этнографы, исследователи эпохи бронзы и раннего железа - А.М. Оразбаев и М.К. Кадырбаев, древнетюркской эпохи - Ф.Х. Арсланова, кыпчакской этнической общности - С.М. Ахинжанов, этнической истории казахов - М.С. Муканов, семейно-брачных отношений у казахов - Х.А. Аргынбаев и многие другие.

Столь впечатляющая состоятельность, естественно, вызывает интерес к личности ученого. От при- 
роды мягкий и добрый человек, он никогда не отзывался ни о ком отрицательно. В целом жизнь его для постороннего глаза была на редкость однообразной. Преданность научной проблеме, видение в ее разрешении смысла жизни, всесторонняя образованность, гуманность, бескорыстие, не суетливость, достоинство, способность жертвовать собой были свойственны ему, составляли его человеческую суть. По существу, это общие моменты, сближающие ученых-творцов. Специфика общественных, гуманитарных наук такова, что ученый-творец должен любить свой предмет и, если его предмет - история культуры, история народа, то ученый должен любить свою культуру, свою историю, свой народ, поскольку творчество в общественных науках не просто получение нового знания, но и понимание смысла бытия народа. Недаром, именно ученые-обществоведы подвергаются репрессиям, именно они открываются в своих пристрастиях, иначе сделать нечто значительное в науках об обществе невозможно. Такие ученые живут настоящими ценностями и потому по-настоящему счастливы, хотя зачастую они не приняты обществом, не обласканы властями.

Избрав еще в юности свой путь в науке, Алькей Хаканович настолько был предан ему, что даже в минуты отдыха как бы был погружен в предмет своего исследования. Так, можно было наблюдать, как поздно вечером Алькей Хаканович, устав, брал в руки домбру и наигрывал кюи, пел любимые им песни. И нам представлялось, что бескрайние степные просторы и древние города, бурлящая в них жизнь вставали перед взором ученого. Красота степи и древних городов, творения их жителей настоль- ко восхищали его, что он как бы сам жил в ту эпоху. Алькей Хаканович не торопился с публикацией трудов, откладывал написанное, позднее вновь возвращаясь к нему. Огромную работоспособность до последних дней жизни можно, с одной стороны, объяснить методом работы, если утомляла работа в одной области исследований, он переходил к другой. К тому же скрупулезная работа с первоисточниками постоянно увлекала его в иные области исследований.

Когда читаешь рукописи А.Х. Маргулана, бросается в глаза большое количество эпитетов в превосходной степени. Ученый не скрывал своего восхищения творениями кочевников. Красота, раскрывавшаяся перед ним, любовь к родной земле, к своему народу были для него родником, из которого он черпал силы на протяжении всей жизни.

Крупнейший исследователь памятников Средней Азии, друг Алькея Хакановича проф. М.Е. Массон в юбилейном приветствии писал, что А.Х. Маргулан «не просто плодотворный исследователь, он принадлежит к той плеяде ученых-энтузиастов, вдохновение которых роднит науку с поэзией. Есть у него общее с деятельностью Чокана Валиханова, чьи произведения он пестовал при их издании. Оба прочно и навсегда вошли в науку»* [*Записи из семейного архива - прим. авт.].

В 2012 г. было завершено издание 14-титомного Собрания сочинений А.Х. Маргулана, осуществлённое по программе «Культурное наследие». В Предисловии к первому тому Собрания сочинений ученого Н.А. Назарбаев написал: «Подвижническая работа великого казахского ученого А.Х. Маргулана и его последователей положила начало позна- 
Маргулан Д.А. Жизнь и научная деятельность А.Х. Маргулана....

нию цивилизации, появившейся на территории Казахстана более 4 тысяч лет назад» [Назарбаев, 1998]. Перед нами стоит задача выпустить полное Собрание сочинений ученого, что позволит оценить титанический труд и понять осуществление грандиозного замысла.

А.Х. Маргулан прожил долгую жизнь и тем не менее поражает громада его научного наследия, диапазон предметных исследований ученого и временной охват истории. Органичное сочетание в нем содержания мировой культуры и традиционных ценностей казахов явились основой появления фундаментальных трудов. Академик Ш.Ч. Чокин в своей книге воспоминаний «Четыре времени жизни» пишет: «То, что он сделал для реставрации духовного наследия народа, выходит за рамки науки и имеет общечеловеческое значение» [Чокин, 1991].

А.Х. Маргулан ушел из этого мира 12 января 1985 года. Он относится к ученым, родившимся в дореволюционную эпоху. Сердцем он из той эпохи, поэтому ему так близок и дорог мир кочевника, со свойственным ему тотемным стилем мышления и трепетным отношением к духу предков, миру мифов и легенд, миру юрты и степных просторов, открытых Космосу.
Академик А.X. Маргулан оставил огромное научное наследие, по предварительным данным состоящее из 14 томов фундаментальных трудов. Только выпуск полного собрания сочинений позволит оценить титанический труд и понять осуществление грандиозного замысла.

Рожденные гением Первого Президента Республики Казахстан Н.А. Назарбаевым национальная программа «Мәңгілік ел» и национальная идея «Рухани жаңғыру» явились велением времени. Без трудов А.Х. Маргулана невозможно глубоко и правильно понять национальную идею и характер преобразований, происходящих в наше время. В них заложены духовные и культурные основы казахов, изучение которых и реконструкция в свете современных глобальных реалий и модернизационных процессов в общественных отношениях позволят донести идеи духовной консолидации, общности культурных ценностей [Назарбаев, 2014; 2017$]$.

Алькей Хаканович Маргулан пришел в этот мир с миссией, которую он достойно выполнил. Человек большого ума и сердца сквозь время приходит к нам сегодня своими трудами.

\section{ЛИТЕРАТУРА}

1. Маргулан А.Х. Очерк жизни и деятельности Ч.Ч. Валиханова // Валиханов Ч.Ч. Собрание сочинений в пяти томах. Алматы: Изд-во АН КазССР, 1961. Т. 1. C. 9-103.

2. Маргулан А.X. Чокан и «Манас»: исследование о Чоканском варианте эпоса «Манас». Под ред. М. Магауина. Алма-Ата: «Жазушы», 1971. 164 с.

3. Маргулан A.X. Собрание сочинений в 14-ти томах. Алматы: «Алатау», 2008a. T. 5. T. $6.494 \mathrm{c}$.

4. Маргулан А.Х. Собрание сочинений в 14-ти томах. Алматы: «Алатау», $2008 б$. T. $8.469 \mathrm{c}$.

5. Маргулан А.Х. Собрание сочинений в 14-ти томах. Алматы: «Алатау», 2008в. 
6. Маргулан А.Х. Собрание сочинений в 14-ти томах. Алматы: «Алатау», 2008г. T. $12.574 \mathrm{c}$.

7. Маргулан А.Х. Собрание сочинений в 14-ти томах. Алматы: «Алатау», 2008д. T. $13.446 \mathrm{c}$.

8. Назарбаев Н.А. Предисловие // Маргулан А.Х. Собрание сочинений в 14-ти томах. Алматы: «Атамура», 1998. Т. 1. С. 5.

9. Назарбаев Н.А. «Мәңгілік Ел» - многовековая мечта о независимости Казахстана. 15.12.2014. URL: http:/www.adilet.gov.kz/ru/leaflet/mngilik-el-mnogovekovayamechta-o-nezavisimosti-kazahstana (дата обращения: 01.10.2018).

10. Назарбаев Н.А. Взгляд в будущее: модернизация общественного сознания. 12.04.2017. URL: http://www.akorda.kz/ru/special/events/akorda_news/press_conferences/statya-glavy-gosudarstva-vzglyad-v-budushchee-modernizaciya-obshchestvennogosoznaniya (дата обращения: 01.10.2018).

11. Степанов Б. Об идеологических ошибках работников общественных наук Казахстана // Большевик Казахстана. 1947. № 1. С. 34-47.

12. Чокин Ш.Ч. Четыре времени жизни: воспоминания и размышления. Алматы: «Білім», 1998. 432 с.

\section{Сведения об авторе:}

Маргулан Данель Алькеевна - спецредактор 14-титомного «Собрания сочинений А.Х. Маргулана» (г. Алматы, Казахстан); dmargulan@list.ru

\section{Ә.Х. МАРҒҰЛАННЫН ӨМІРІ МЕН ҒЫЛЫМИ ҚЫЗМЕТІ. АДАМ ЖӘНЕ ҒАЛЫМ БЕЙНЕСІ}

\section{Д.А. Марғұлан}

Әлкей Хақанұлы Марғұлан - отандық ғылым тарихындағы өте сирек кездесетін құбылыс, Қазақстан археологиясы мен этнографиясының негізін қалаушы. Ә.Х. Марғұлан өз халқының рухани қасиетін зерттеуде алғашқылардың бірі болды, халық тарихындағы ғасырлар бойы тұнған құпияларды алғашқы болып ашты. Қазақстанның батыс шекарасынан бастап Орталық Қазақстан арқылы отанымыздың солтүстік-шығыс және шығысына дейін ондаған мың шақырымды жүріп өтіп, ол қола және ерте темір дәуірінен бастап кейінгі ортағасырларға дейінгі ескерткіштерді ашып, сипаттады, қазақ халқының салты мен дәстүрін, эпикалық әңгімелерін, аңыздарды, қазақ тайпаларының қоныстанған жерлерін зерттеді.

Түйін сөздер: археология, Ә.Х. Марғұлан, ғылым тарихы, алғашқы, археолог, этнограф, фольклорист

\section{LIFE AND SCIENTIFIC ACTIVITY OF A. KH. MARGULAN. IMAGE OF SCIENTIST AND PERSON}

\section{D.A. Margulan}

Alkey Kh. Margulan is phenomenon in the history of national science, founder of archaeology and ethnography in Kazakhstan. A.Kh. Margulan was pioneer in the study of spiritual sanctuaries of his people, pioneer for centuries hidden secrets of the history of the people. Having traveled tens of thousands of kilometers across Kazakhstan from its western borders across Central Kazakhstan to the northeastern and eastern limits of our homeland, he discovered and described monuments of material culture from the Bronze Age and early nomads to the late Middle Ages, studied customs and traditions of Kazakhs, epic tales, legends and stories, places of living of Proto-Kazakh tribes.

Keywords: archaeology, A.Kh. Margulan, history of science, pioneer, archeologist, ethnographer, folklorist 


\section{REFERENCES}

1. Margulan, A. Kh. 1961. In Valihanov Ch.Ch. Sobranie sochinenii v 5 tomah (Collected works in 5 volumes), 1. Almaty: Academy of sciences of KazSSR Publ., 9-103 (in Russian).

2. Margulan, A. Kh. 1971. Chokan $i$ «Manas»: issledovanie o Chokanskom variante eposa "Manas" (Chokan and "Manas": a study on the Chokan variant of the epos "Manas"). M. Magauin (Ed.). Alma-Ata: «Zhazushy» Publ. (in Russian).

3. Margulan, A. Kh. 2008a. Sobranie sochinenii v 14-ti tomah (Collected Works in 14 volumes). T. 5. Almaty: "Alatau» Publ. (in Russian).

4. Margulan, A. Kh. 20086. Sobranie sochinenii v 14-ti tomah (Collected Works in 14 volumes). T. 6. Almaty: «Alatau» Publ. (in Russian).

5. Margulan, A. Kh. 2008в. Sobranie sochinenii v 14-ti tomah (Collected Works in 14 volumes). T. 8. Almaty: «Alatau» Publ. (in Russian).

6. Margulan, A. Kh. 2008г. Sobranie sochinenii v 14-ti tomah (Collected Works in 14 volumes). T. 12. Almaty: «Alatau» Publ. (in Russian).

7. Margulan, A. Kh. 2008д. Sobranie sochinenii v 14-ti tomah (Collected Works in 14 volumes). T. 13. Almaty: «Alatau» Publ. (in Russian).

8. Nazarbayev, N. A. 1998. In Margulan A.Kh. Sobranie sochinenii v 14-ti tomah (Collected Works in 14 volumes), 1. Almaty: «Atamura» Publ., 5 (in Russian).

9. Nazarbayev, N. A. 2014. In URL: http://www.adilet.gov.kz/ru/leaflet/mngilik-elmnogovekovaya-mechta-o-nezavisimosti-kazahstana (in Russian).

10.Nazarbayev, N. A. 2017. In URL: http://www.akorda.kz/ru/special/events/akorda_news/press_conferences/statya-glavy-gosudarstva-vzglyad-v-budushchee-modernizaciya-obshchestvennogo-soznaniya (in Russian).

11. Stepanov, B. 1947. In Bolshevik Kazahstana (Bolshevik of Kazakhstan), 1, 34-47 (in Russian).

12.Chokin, Sh. Ch. 1998. Chetyre vremeni zhizni: vospominaniya i razmyshleniya (Four times of life: memories and reflections). Almaty: «Bilim» Publ. (in Russian).

\section{About the Author:}

Margulan Danel A. Special Editor of the "Collected Works of A.Kh. Margulan" in 14 volumes, Almaty, Kazakhstan; dmargulan@list.ru

\footnotetext{
Мүдделер қақтығысы туралы ақпаратты ашу. Автор мүдделер қақтығысының жоқтығын мәлімдейді. / Раскрытие информации о конфликте интересов. Автор заявляет об отсутствии конфликта интересов. / Disclosure of conflict of interest information. The author claims no conflict of interest.

Мақала туралы ақпарат / Информация о статье / Information about the article. Редакцияға түсті / Поступила в редакцию / Entered the editorial office: 15.10 .2018 . Рецензенттер мақұлдаған / Одобрено рецензентами / Approved by reviewers: 22.10.2018. Жариялауға қабылданды / Принята к публикации / Accepted for publication: 27.10.2018.
} 